\title{
Employee engagement in Nigeria: The role of leaders and boundary variables
}

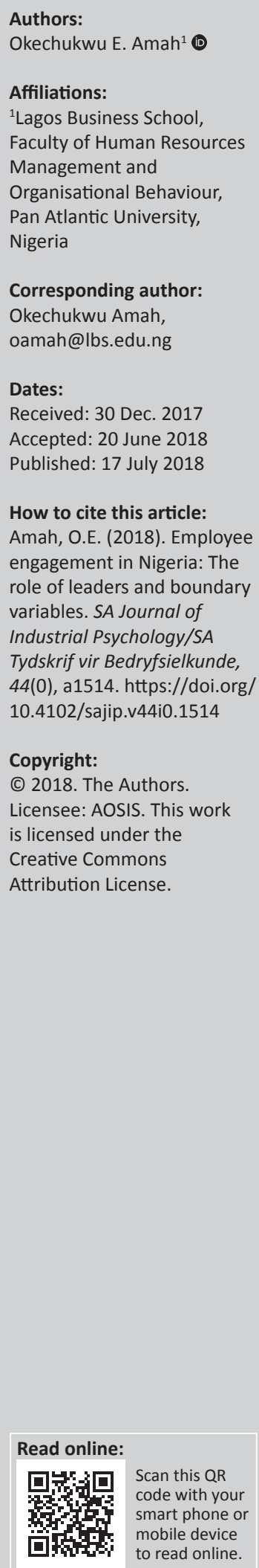

Orientation: Engaged employees make a valuable contribution to organisational agility and productivity in challenging business environments. Hence, identifying factors that enhance employee engagement is important in the Nigerian context.

Research purpose: The objectives of this study were to show that various leadership styles have different effects on employee engagement, and that the employee voice and the perception of organisational support are boundary variables through which leadership style affects employee engagement.

Motivation for the study: High unemployment rate and job insecurity in Nigeria make it necessary to determine leadership styles and other factors that enhance employee engagement.

Research design, approach and method: Cross-sectional survey design was used with samples taken from organisations located in Lagos, Nigeria $(n=300)$. Existing measures of study variables that have been validated were used for the study. Statistical Package for the Social Sciences (SPSS) and structural equation modelling techniques were used for data analysis.

Main findings: The relationship between leadership style and employee engagement is not direct but mediated through boundary variables, employee voice and perception of organisational support. Servant leadership style has the highest total effect on employee engagement. Autocratic style is detrimental to the engagement of employees. Encouraging employee voice enhances the employee's perception of the organisation as supportive.

Practical/managerial implications: Though leadership is known to be the main driver of employee engagement, not all leadership styles enhance employee engagement. The effect of leadership on employee engagement is influenced by the favourable environment created by the leader's behaviour. Organisations must use the determination of potential leadership style as recruitment tool for new managers and those to be promoted. The performance evaluation of leaders must include behavioural factors that capture leaders' ability to create a favourable environment that encourages the employee voice and perception of organisation as supportive.

Contribution/value-add: Leadership styles are not equally effective in enhancing employee engagement. There are boundary variables arising from the environment created by leadership behaviour that enhance the effect of leadership style on employee engagement. The study was performed in Nigeria where high unemployment rate and job insecurity created a unique challenge in getting employees engaged.

\section{Introduction}

In the 21st century, organisations must be swift to take advantage of opportunities and manage threats that are constantly arising in their environment (Sriram, 2012). Hence, organisations require the services of employees who are willing to go the extra mile (work outside assigned job roles) needed to create an agile organisation (Amah \& Sese, 2018). Engaged employees apply themselves totally (body, soul and emotion) to their assigned roles and perform extra role activities not stipulated in their job responsibilities but that are necessary for superior organisational productivity (Amah \& Sese, 2018). Employee engagement is known to have a positive effect on organisational and individual productivity and performance (Amah \& Sese, 2018). Some of the drivers of employee engagement are leadership behaviour and the organisational climate created by leaders and relationships within the organisation (May, Gilson, \& Harter, 2004; Rees, Alfes, \& Gatenby, 2013; Rothmann \& Rothmann, 2010; Ugwu, Onyishi, \& Rodriguez-Sanchez, 2014). Reviewing the various drivers of employee engagement, Kruse (2012) concluded that leadership style holds the key to employee engagement as other factors are directly or indirectly affected by the leadership style of the manager. Leadership creates an organisational climate in which employees develop relationships and perform (Amah, 2018). The role of employee engagement in the productivity 
and performance of organisations makes leadership role even more important. This is because engaged employees provide the needed competitive advantage for organisations (Amah \& Sese, 2018). In search of the most effective leadership style, value-based leadership styles have gained the most prominence (Dean, 2008). Value-based leadership includes transformational, autocratic leadership (AL), transactional leadership (TL) and servant leadership (SL).

Servant leadership is one value-based leadership style that is known to be superior to other value-based styles (Hoch, Bommer, Dulebohn, \& Wu, 2018). For example, SL, AL and TL styles are driven by different motives in leadership and affect employees differently. The main motive for SL style is to serve employees so that they develop to their highest potential (van Dierendonck, 2011). Employees are the end of the servant leaders' efforts, while organisational performance is secondary (Chan \& Drasgow, 2001). This does not mean that servant leaders do not value organisational productivity; however, they believe that superior productivity is the outcome of well-developed employees. Both AL and TL styles emphasise organisational productivity with less emphasis on people development (Graen, Liden, \& Hoel, 1982). Organisational performance is the end of both styles with people being the means to the end (Levinson, 1980).

Past studies addressed the effect of a single leadership style on employee engagement and work outcomes (Breevaart et al., 2014; Zhang \& Bartol, 2010), how organisational resources and job demand affect employee engagement (Hanninen, 2017) and how voice relate to the feeling of being engaged (Robinson, 2018). However, the current study builds on these past studies and investigated how leadership styles differentially affect employee engagement when they appear as variables in the same model. The direct effects of leadership styles have; however, been inferred by way of theorising and correlation analysis (see Kruse, 2012; Young, 2014). Furthermore, calls have been made for studies to establish boundary variables that have the potential to affect the relationship between leadership style and employee engagement (Breevaart et al., 2014; Wang \& Hsieh, 2013). A way to identify the boundary variables is to consider the variables in the organisational climate created by different leadership styles. Two such variables are employee voice (EV) and perception of organisational support (POS). In a climate that allows EV, employees freely and without fear of consequence communicate ideas and opinions with the intent of improving individual and organisational productivity (Morrison, Wheeler-Smith, \& Kamdar, 2011). Perception of organisational support arises when employees believe that the organisation cares about them and values their contributions. It is postulated in this study that EV and POS will act as boundary variables whose presence will affect the strength of the relationship between leadership style and employee engagement.

The current study has three aims. The first is to determine the differential effects of AL, TL, and SL styles on employee engagement; the second is to explore if the above relationships are direct or mediated by two boundary variables, EV and POS. In doing these, the study made the following contributions. Firstly, it established the role played by different leadership styles in enhancing employee engagement. Past studies have implied this relationship but none has empirically proved the inference by testing the effects of many leadership styles in the same model (Breevaart et al., 2014; Gregory Stone, Russell, \& Patterson, 2004). Secondly, the study filled a gap identified in past leadership and engagement literature by establishing boundary variables that enhance the strength of the relationship between leadership style and employee engagement. Lastly, the study was conducted in Nigeria, a country with peculiar human resources management issues, created by a high unemployment rate and job insecurity. Nigeria with an estimated working population of 109 million (out of a population of 180 million) has one of the highest unemployment rates in the world (National Bureau of Statistics June 2017, Nigeria). The few people in employment face job insecurity owing to frequent job loss occasioned by poor economic indicators. For example, when the Nigerian economy went into recession in 20162017, it was estimated that over 3.7 million people lost their jobs (National Bureau of Statistics June 2017, Nigeria). Job insecurity is associated with lack of trust and confidence. Engaging employees in an environment of lack of trust and confidence is a challenge, and leadership creates the environment in which trust is built (Khan, 2015). Hence, understanding the relationship between leadership style and employee engagement, and boundary variables that can enhance such a relationship is a worthy course of action in the Nigerian environment.

\section{Theory and hypotheses Employee engagement and leadership styles}

Engaged employees apply themselves totally (physical, mental and emotional) to their job role (Kahn, 1990). Kahn identified three states that employees must pass through before achieving full engagement. These are psychological meaningfulness, availability and safety. Psychological meaningfulness occurs when individuals perceive that they are obtaining equal or greater benefits compared to their investment of physical, mental and emotional efforts in the work role. Employees are psychologically safe when they perceive that they can express themselves in their work without negative consequences towards self-image, career or status (Kahn, 1990). Psychological availability refers to the perception that one has enough physical, emotional, and mental resources to engage in work at any moment in time (Kahn, 1990). Engaged employees make a valuable contribution to the productivity and image of the organisation and have positive work attitudes (Anikan \& Oyewole, 2014; Harter, Schmidt, \& Hayes, 2002; Ugwu, 2013; Young, 2014). The three main drivers of employee engagement are leadership style, organisational climate and individual dispositions (Anikan \& Oyewole, 2014; Ugwu, 2013). Commenting on leadership as the main driver of engagement, Young (2014) stated that leadership behaviour holds the key to the improvement of 
engagement and that the correlation between leadership and engagement is as high as 0.6. Kruse (2012) had earlier itemised that the leadership behaviours that affect engagement include communication, growth and development of employees, reward and recognition, trust and confidence, and emotional intelligence.

Employee engagement is an outcome of good employment relations, driven by the behaviour of leaders in the organisation (Koene, Vogelaar, \& Soeters, 2002). Leadership styles have foundational motives and such motives are reflected in the leadership behaviours. For example, the motivation behind the AL and TL styles is fuelled by the inward mindset and interests of the leader rather than those of the employees. Both leadership styles see employees as means to an end (Lavinson, 1980). The success of TL is hinged on the leader's ability to appeal to the follower's self-interest (Lavinson, 1980). Hence, it is argued that TL behaviour cannot drive employees to put in a discretionary effort to help the organisation succeed, as employees concentrate on meeting only the agreed objectives (Levinson, 1980). Autocratic leaders maintain absolute authority over employees, demand unquestionable obedience, practise unilateral decisionmaking and create a widening power distance between them and employees (Cheng, Chou, Wu, Huang, \& Farh, 2004). In doing these, the leader achieves full control over employees to achieve desired goals (Schuh, Zhang, \& Tian, 2013). The widening power distance is viewed by employees as apathy towards their own interests. For example, an autocratic leader will ignore employees' suggestions and play down their contributions towards the success of the organisation (Aryee, Chen, Sun, \& Debrah, 2007). Thus, the environments created by transactional and autocratic leaders are characterised by one-way communication, based purely on exchange principles with no emotional attachment, devoid of trust and confidence, low emotional intelligence and poor development of employees (Hollander, 1986). Such an environment is de-energising to employees. By the theory of social exchange and norm of reciprocity, employees in such environments will not invest in their work role by being engaged as the cost is more than what they get out of work. This violates the principle of psychological meaningfulness. Hence, the following hypotheses are postulated:

H1a: Autocratic leadership style is negatively related to employee engagement.

H1b: Transactional leadership style is negatively related to employee engagement.

The motive for SL is to serve the employees so that they give their best to achieve organisational productivity. The servant leader's priority is to build relationship with his followers through joint decision-making as a means of getting employees to engage in activities that will benefit the organisation (Gregory Stone et al., 2004; Savage-Austin \& Honeycutt, 2011). Thus, the success of SL lies in employees' willingness to provide a discretionary effort as opposed to achieving only what is expected of them. Such leadership behaviour will encourage two-way communication, emotional attachment between leader and follower, build trust and confidence, and help employees to develop high emotional intelligence. Employees benefiting from these positive behaviours will reciprocate by way of high employee engagement. The three principles, namely, psychological meaningfulness, safety and availability are satisfied in the environment created by servant leaders. Based on the arguments above, the following hypothesis is postulated:

H1c: Servant leadership style is positively related to employee engagement.

\section{Mediators of the relationship between leadership style and employee engagement}

Employee voice is described as the discretionary verbal communication of ideas, suggestions or opinions by employees with the intention of improving individual and organisational performance (Morrison et al., 2011). Leadership attitude and beliefs on EV will affect the tendency for employees to make suggestions on improving organisational outcomes (Amah \& Okafor, 2008a; Gul, Ahmad, Rehman, Shabir, \& Razzaq, 2012). In leadership behaviours that do not encourage voice, employees will perceive high cost to themselves and career if they voice out issues about the organisation, especially those perceived as negative by such leaders (Amah \& Okafor, 2008a; Vakola \& Dimitris, 2005). Servant leadership style values employees and develops them to their full capability. It allows EV in whatever is important in the organisation as its essence is the full development of employees (Amah \& Sese, 2018). Autocratic style is based on one-way communication in which the leader tells the employees what to do, how to do it and when to do it, and autocratic leaders believe that employees are meant to follow orders and not to offer suggestions (Cheng et al., 2004). Hence, the climate created by this style will not favour EV. Transactional leadership style values employees only on exchange basis. It will allow EV provided it is meant to pursue the interest of the leader. Employee voice may be encouraged, but employees may also not feel very comfortable using such voice for fear of consequences (Amah \& Sese, 2018). Engaged employees are always seeking to improve efficiency in their job, hence the more voice they are allowed, the higher they are engaged (Amah \& Sese, 2018). Highly engaged employees are always identifying ways to improve personal and organisational productivity (Amah \& Sese, 2018). In an environment in which EV is encouraged, engaged employees will utilise voice to make suggestions aimed at improving the work process and to enhance their productivity (Budd \& Zagelmeyer, 2010). By the theory of social exchange and norms of reciprocity, such employees have high level of engagement. Hence, the following hypotheses are postulated:

H2a: Autocratic leadership style is negatively related to employee voice.

H2b: Transactional leadership style is negatively related to employee voice.

H2c: Servant leadership is positively related to employee voice.

H2d: Employee voice is positively related to employee engagement. 
Amah and Okafor (2008b, p. 494) define POS as, 'the perception of employees that the organisation values their contribution'. An environment of high POS is created by leadership behaviours that value and care for people. A social exchange theory has always been used to explain how POS affects employees' work outcome, including work attitudes (Eisenberger, Huttington, Hitchinson, \& Sowa, 1986). The servant leadership style creates an environment that values people and provides them with the means to be effective. The style will create a climate which will be perceived by employees as supportive. On the contrary, both AL and TL styles do not value employees and thus will create environments that will be perceived as unsupportive (Amah, 2017). Highly engaged employees will perceive high POS as a confirmation that the organisation values the personal sacrifices they make in being highly engaged. Hence, such employees will feel obligated to make a more discretionary effort to benefit the organisation. Greater perceived organisational support is expected to produce greater affective emotional attachment and feelings of obligation towards the organisation based on social exchange theory and norms of reciprocity (Allen, Shore, \& Griffeth, 2003). Hence, the following hypotheses are postulated:

H3a: Servant leadership is positively related to the perception of organisational support.

H3b: Autocratic leadership style is negatively related to the perception of organisational support.

H3c: Transactional leadership style is negatively related to the perception of organisational support.

H3d: The perception of organisational support is positively related to employee engagement.

The model tested is shown in Figure 1.

\section{Research design \\ Research approach}

The study was based on a cross-sectional survey design and quantitative method of analysis. Data were acquired through

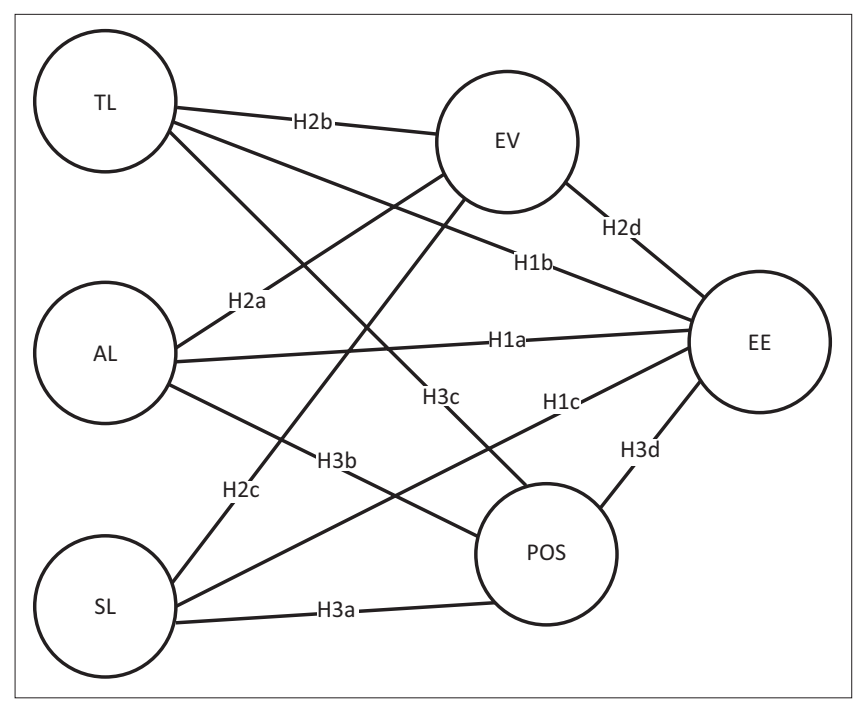

$\mathrm{TL}$, transactional leadership; AL, autocratic leadership; SL, servant leadership; EV, employe voice; POS, perception of organisational support; $\mathrm{EE}$, employee engagement.

FIGURE 1: Hypothesised model. questionnaires administered to randomly selected participants in organisations located in the city of Lagos, Nigeria. The questionnaires were administered between the period of July and October 2017. The organisations came from three industries, namely, oil, financial and manufacturing.

\section{Research method}

\section{Participants}

A total of 1000 questionnaires were distributed to randomly selected participants in five organisations. After two reminders, 300 usable questionnaires were returned $(30 \%$ return rate). The characteristics of the participants are displayed in Table 1. Forty-four per cent of the participants came from the financial industry, $49 \%$ are male, $47 \%$ have a first degree or a postgraduate degree, $55 \%$ are between the ages 31 and 50 years and $67 \%$ have been in their organisations for less than 10 years.

\section{Measuring instruments}

The transactional leadership style was measured on a fiveitem scale adopted from Ismail, Mohamad, Mohamed, Rafiuddin and Zhen (2010). An item is, for example: 'My manager/supervisor monitors my performance and keeps track of my mistakes'. The servant leadership style was measured on a seven-item scale taken from the work of Liden et al. (2015). For example: 'My manager/supervisor instils prides and respect in others and inspires me by being highly competent'. The autocratic leadership style was measured on a nine-item scale taken from the work of Cheng et al. (2004). For example: 'I have to follow my manager/supervisor's rules to get things done, if not I get punished severely'. The perceived organisational support is measured on a six-item scale adopted from the work of Eisenberger, Armeli, Rexwinkel, Lynch and Rhoades (2001). For example: 'My organisation shows great care for me'. The employee voice is measured on a six-item scale adopted from the work of van Dyne and LePine (1998). For example: 'I speak up and encourage others in my organisation to speak up concerning issues that affect my organisation'. Employee engagement is

TABLE 1: Characteristics of the participants.

\begin{tabular}{llcc}
\hline Items & Category & Frequency & $\mathbf{\%}$ \\
\hline Industry & Oil & 100 & 33 \\
& Financial & 130 & 44 \\
& Manufacturing & 70 & 23 \\
Gender & Male & 148 & 49 \\
& Female & 150 & 50 \\
\multirow{3}{*}{ Age } & Missing & 2 & 1 \\
& Under 30 years & 74 & 25 \\
& 31-40 years & 102 & 34 \\
& 41-50 years & 64 & 21 \\
Years of service & Above 50 years & 60 & 20 \\
& Less than 5 years & 30 & 10 \\
& 6-10 years & 200 & 67 \\
\multirow{2}{*}{ Education level } & Above 10 years & 70 & 23 \\
& Secondary school & 74 & 25 \\
& Diploma & 85 & 28 \\
& Degree & 97 & 32 \\
& Postgraduate & 44 & 15 \\
\hline
\end{tabular}


conceptualised as how employees apply themselves to assigned work roles and is reflected in their vigour, dedication and absorption. It was measured on a short scale taken from the work of Schaufeli, Bakker and Salanova (2002). For example: 'At work, I feel strong and vigorous'. Cronbach's alpha from past studies for all the measures used in this study vary between 0.75 and 0.85 . Despite this, the measures were validated to ensure the accuracy of their use in this study.

\section{Research procedure}

The human resource managers from each organisation reviewed the questionnaires prior to distribution to ensure that no confidential information was involved and that no ethical issue was violated. A research assistant worked with designated individuals from each organisation to distribute the questionnaires directly to the randomly selected participants in each organisation. The filled-outquestionnaires were returned in sealed envelopes provided by the research assistant. Participants were assured that confidentiality would be maintained and that the ultimate results would not be given to their organisations in a format that would reveal their identities.

\section{Data analysis}

Analysis of data were carried out using SPSS 23 and Analysis of Moments Structures (AMOS 25). Model fit was judged for goodness of fit index (GFI), comparative fit index (CFI) and root-mean-standard-error of approximation (RMSEA). For a model to be described as having good fit, CFI and GFI must be 0.9 and above, and RMSEA should be between 0.05 and 0.08 (Hu \& Bentler, 1999).

\section{Common method analysis}

Six factors were extracted in an unrotated factor analysis, with the first factor extracting only $20 \%$ of the variance when compared with $73 \%$ extracted by the other five factors. Hence, common method variance was not an issue in the analysis (Podsakoff \& Organ, 1986).

\section{Multivariant normality, construct, convergent and discriminant validity analysis}

A condition for using structural equation modelling is that the distribution of the data must satisfy the multivariant normality test. The multivariant kurtosis obtained is 1.99 with critical ratio of 1.80 which is within the range of kurtosis and critical ratio of \pm 2.58 and \pm 1.96 , respectively, recommended by Hair, Black, Babin, Anderson and Tatham (2010). Construct validity shows the extent to which the items for a factor load exclusively on the factor. The item loadings in Table 2 are all above the cut-off point of 0.5 which indicates acceptable construct validity (Hair et al., 2010). Convergent validity measures the level of correlation between the items that measure the same factor. Convergent validity is established when factor loadings exceed 0.5 (Hair et al., 2010). Cronbach's alpha is more than 0.70 (Nunnally, 1978), and average variance extracted more than 0.5 (Hair et al., 2010). Table 2 indicates that these conditions are satisfied. Discriminant validity is established by comparing the variance extracted by each factor with the correlations the factor has with other factors (Koufteros, Vonderembse \& Doll, 2002). Each diagonal element in Table 3 is greater than its vertical and horizontal off diagonal elements showing evidence of discriminant validity.

\section{Results}

\section{Descriptive statistics, alpha coefficients and correlations}

Descriptive statistics, Cronbach's alpha coefficients and correlations for the study variables SL, AL, TL, EV, employee engagement and POS are presented in Table 4. The figures in the table indicate that the Cronbach's alpha coefficients for all the study variables are above the acceptable value of 0.7. Construct, convergent and discriminant validities are adequate. Hence, the results obtained with the estimation method are reliable. All the study variables are positively correlated with employee engagement. The correlations involving the AL and TL styles are opposite of what was hypothesised. The means for the SL, AL and TL styles are 3.99, 4.25 and 4.47, respectively. This shows that fewer leaders exhibited SL behaviour in the sampled organisations.

TABLE 2: Convergent validity.

\begin{tabular}{|c|c|c|c|c|}
\hline Construct & Loadings & $\begin{array}{l}\text { Cronbach's } \\
\text { alpha }\end{array}$ & $\begin{array}{c}\text { Average } \\
\text { variance } \\
\text { extracted }\end{array}$ & $\begin{array}{l}\text { Composite } \\
\text { reliability }\end{array}$ \\
\hline Employee engagement & $\begin{array}{l}0.673 \\
0.691 \\
0.661 \\
0.644\end{array}$ & 0.900 & 0.622 & 0.680 \\
\hline Employee voice & $\begin{array}{l}0.669 \\
0.723 \\
0.778 \\
0.726\end{array}$ & 0.800 & 0.874 & 0.702 \\
\hline Servant leadership & $\begin{array}{l}0.752 \\
0.773 \\
0.731 \\
0.732 \\
0.773\end{array}$ & 0.930 & 0.720 & 0.650 \\
\hline Autocratic leadership & $\begin{array}{l}0.714 \\
0.740 \\
0.680 \\
0.667\end{array}$ & 0.880 & 0.700 & 0.640 \\
\hline Transactional leadership & $\begin{array}{l}0.798 \\
0.728 \\
0.816 \\
0.752\end{array}$ & 0.910 & 0.740 & 0.650 \\
\hline $\begin{array}{l}\text { Perception of organisational } \\
\text { support }\end{array}$ & $\begin{array}{l}0.821 \\
0.803 \\
0.823 \\
0.816\end{array}$ & 0.820 & 0.790 & 0.800 \\
\hline
\end{tabular}

TABLE 3: Discriminant validity.

\begin{tabular}{lcccccc}
\hline Variables & $\mathbf{1}$ & $\mathbf{2}$ & $\mathbf{3}$ & $\mathbf{4}$ & $\mathbf{5}$ & $\mathbf{6}$ \\
\hline 1. Employee engagement & $\mathbf{0 . 7 1 *}$ & - & - & - & - & - \\
2. Servant leadership & 0.27 & $\mathbf{0 . 7 2 *}$ & - & - & - & - \\
3. Autocratic leadership & 0.15 & 0.17 & $\mathbf{0 . 7 0 ^ { * }}$ & - & - & - \\
4. Transactional leadership & 0.19 & 0.25 & 0.30 & $\mathbf{0 . 7 4 *}$ & - & - \\
5. Perception of support & 0.23 & 0.25 & 0.18 & 0.30 & $\mathbf{0 . 7 9 *}$ & - \\
6. Employee voice & 0.19 & 0.15 & 0.12 & 0.19 & 0.21 & $\mathbf{0 . 7 3 *}$ \\
\hline
\end{tabular}

Note: Diagonal items are average variance extracted; off diagonals are square of correlation. $*, p<0.05$. 
TABLE 4: Descriptive statistics, alpha coefficient and correlations.

\begin{tabular}{|c|c|c|c|c|c|c|c|c|c|c|c|c|}
\hline Variables & Mean & SD & 1 & 2 & 3 & 4 & 5 & 6 & 7 & 8 & 9 & 10 \\
\hline 1. Gender & - & - & - & - & - & - & - & - & - & - & - & - \\
\hline 2. Age & - & - & $0.17 *$ & - & - & - & - & - & - & - & - & - \\
\hline 3. Tenure & - & - & 0.02 & 0.11 & - & - & - & - & - & - & - & - \\
\hline 4. Education & - & - & 0.04 & $0.16^{*}$ & 0.03 & - & - & - & - & - & - & - \\
\hline 5. Employee engagement & 4.34 & 1.37 & -0.11 & 0.03 & $0.21 * *$ & 0.06 & 0.90 & - & - & - & - & - \\
\hline 6. Servant leadership & 3.99 & 1.50 & -0.09 & -0.13 & 0.11 & 0.06 & $0.52 * *$ & 0.93 & - & - & - & - \\
\hline 8. Transactional leadership & 4.47 & 1.37 & -0.07 & 0.13 & 0.01 & $0.50 * *$ & $0.44 * *$ & $0.50 * *$ & $0.55 * *$ & 0.91 & - & - \\
\hline 9. Perception of support & 4.34 & 1.47 & -0.08 & -0.08 & 0.11 & 0.05 & $0.48 * *$ & $0.50 * *$ & $0.43 * *$ & $0.55 * *$ & 0.82 & - \\
\hline 10. Employee voice & 4.55 & 1.26 & -0.08 & 0.04 & $0.18^{*}$ & 0.07 & $0.44 * *$ & $0.39 * *$ & $0.35 * *$ & $0.44 * *$ & $0.46 * *$ & 0.88 \\
\hline
\end{tabular}

SD, standard deviation.

$*, p<0.05 ; * *, p<0.01$.

Note: Diagonal items are Cronbach's alpha.

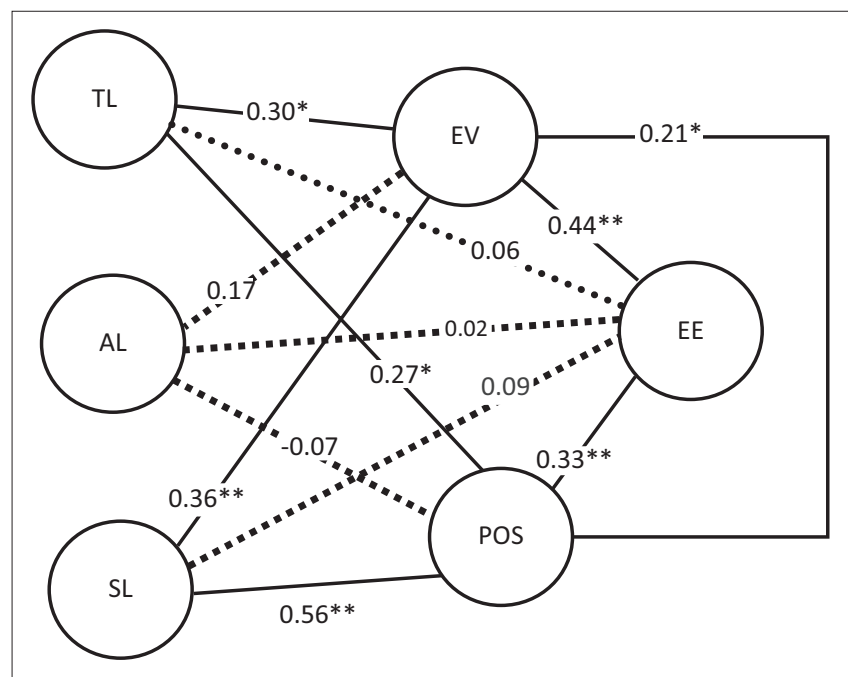

$\mathrm{TL}$, transactional leadership; AL, autocratic leadership; SL, servant leadership; EV, employee voice; POS, perception of organisational support; $\mathrm{EE}$, employee engagement;

Note: Dotted lines are not significant

$*, p<0.05 ; * *, p<0.01$.

FIGURE 2: Estimated model.

\section{Multivariate statistics}

After the initial estimation of the hypothesised model, modification index recommended a relationship between $\mathrm{EV}$ and POS. This relationship is implied in the work of Vakola and Dimitras (2005). Estimation of the new alternative model showed that the new model has better fit and this was confirmed by the $\chi^{2}$ difference test. The estimated model is in Figure 2, while the goodness of fit statistics are in Table 5. None of the leadership styles has a significant direct relationship with employee engagement as hypothesised. Thus, Hypotheses 1a $(\beta=0.02, t=0.751, p=0.317), 1 \mathrm{~b}(\beta=$ $0.09, t=0.762, p=0.446)$ and $1 \mathrm{c}(\beta=0.06, t=0.748, p=0.443)$ are not supported. The relationship between AL and EV is not significant $(\beta=0.17, t=1.911, p=0.056)$, thus $\mathrm{H} 2 \mathrm{a}$ is not supported. The relationship between TL and EV is positive and significant $(\beta=0.30, t=2.277, p=0.023)$, thus $\mathrm{H} 2 \mathrm{~b}$ is supported but in opposite direction. The relationship between SL and EV is significant $(\beta=0.36, t=3.726, p=0.001)$, thus $\mathrm{H} 2 \mathrm{c}$ is supported. Employee voice is positively related to employee engagement $(\beta=0.21, t=3.179, p=0.01)$, thus $\mathrm{H} 2 \mathrm{~d}$ is supported. Servant leadership is positively related to POS $(\beta=0.56, t=7.235, p=0.001)$, thus H3a is supported.
The relationship between AL and POS is not significant $(\beta=-0.07, t=-1.062, p=0.288)$, thus H3b is not supported. Transactional leadership is positively related to POS $(\beta=0.27$, $t=2.797, p=0.005)$, thus $\mathrm{H} 3 \mathrm{c}$ is supported but in the opposite direction. Perception of organisational support is positively related to employee engagement $(\beta=0.33, t=3.838, p=0.001)$, thus $\mathrm{H} 3 \mathrm{~d}$ is supported. Employee voice is positively related to POS $(\beta=0.21, t=3.179, p=0.01)$. This relationship was not hypothesised but recommended by the modification index. The model explained $51 \%$ of the variance in employee engagement. Autocratic leadership, TL and SL have standardised indirect effects of $0.063,0.24$ and 0.37 on employee engagement, respectively (there were no significant direct effects). Thus, SL explained more variance in the value of employee engagement when compared with other leadership styles.

\section{Discussion}

The objectives of this study were to show that various leadership styles have different effects on employee engagement, and that EV and POS are boundary variables through which the leadership styles affect employee engagement. The results indicate that none of the leadership styles has a direct relationship with employee engagement. Employee voice and POS served as pathways through which leadership styles affect employee engagement. Servant leadership has the highest total effect on employee engagement. This is not surprising because SL has the primary motive to serve employees, so that they develop to their highest potential. Servant leadership provides the three principles of psychological meaningfulness, safety and availability which enhance employee engagement (Kahn, 1990). Servant leadership creates a very favourable climate in which engaged employees feel comfortable to voice their concerns and feel that the organisation supports them. Autocratic leadership style did not affect EV and POS. Autocratic leaders engage only in one-way communication and rarely encourage their subordinates to voice their concerns. The autocratic leader believes that employees are only meant to take orders and not make contributions. Such a leadership style will neither create an environment that favours EV nor be perceived as supportive to the employees. The transactional leadership style has significant positive 
TABLE 5: Estimation indices for tested models.

\begin{tabular}{lllllll}
\hline Tested models & $\chi^{2}$ & df & $\Delta \chi^{2}$ & $\chi^{2} /$ df & GFI & CFI \\
\hline Hypothesised model & 77.326 & 40 & & 1.933 & 0.94 & 0.97 \\
Alternate model & 67.527 & 39 & $9.799 * *$ & 1.731 & 0.95 & 0.98 \\
\hline
\end{tabular}

$\chi^{2}$, Chi-square; $d f$, degree of freedom; GFI, goodness of fit index; CFI, comparative fit index; RMSEA, root-mean-square-error of approximation.

$*, p<0.01$.

relationships with EV and POS, contrary to what was hypothesised, and has also been established to have positive relationship with other employee variables (Gul et al., 2012). Thus, transactional leaders create environments that favour EV and are supportive to employees. Although the motive for TL behaviour is not directed towards employee development, such leaders may allow voice provided it will enhance the social exchange process and be beneficial to the parties in the social exchange process. This may be what happened in the study. If the exchange process is perceived as fair, employees may perceive the organisation as supportive, hence the positive relationship between TL and POS, and between TL and EV. However, as the identification of the above reasons is outside the current study, future study might find this interesting.

The employee voice was found to be positively related to POS. The employee voice is affected by the attitude of the supervisor and top management to silence and communication opportunities (Vakola \& Dimitras, 2005). Supervisor and top management positive attitude to employee voice enhances employees' performance. Hence, employees would perceive such an attitude as positive social exchange currency and a sign of support, which must be reciprocated based on the law of reciprocity (Blau, 1964; Gouldner, 1960). This accounts for the positive relationship between EV and POS.

Employee voice and POS are positively related to employee engagement and account for $19 \%$ and $11 \%$ of the variance in employee engagement, respectively. Engaged employees are very creative and willing to make suggestions to improve organisational productivity. Thus, EV is very important to engaged employees, and they require psychological safety to exercise this voice. Engaged employees want to be assured of psychological availability so that they have the support of the organisation as they expend resources to enhance organisational productivity. Thus, environments that are favourable to the enactment of EV and offer support to employees will enhance their engagement. None of the leadership styles has a significant direct relationship with employee engagement, but SL and TL styles have significant indirect relationships with employee engagement through POS and EV (0.37 and 0.24), respectively. The fact that EV and POS mediated the relationship between two leadership styles and employee engagement has significant practical implication. The employee voice and POS thrive in a favourable environment created by leaders. Hence, organisations must be interested in the type of environment created by leaders and the nature of their interactions with their subordinates. This becomes very critical when it is observed that all the leadership styles are not equally effective in creating such an environment. A follow-up managerial implication is that organisations must recruit new leaders or promote internally based leaders who possess the SL characteristics. Amah (2018) established that self-efficacy, motivation-to-serve and motivation-to-lead are antecedents of SL. Thus, human resources managers can use these variables as recruitment and promotion criteria to identify those who can be potential servant leaders. It has been confirmed that establishing these variables in the entry point predicted future leadership behaviour (Chan \& Drasgow, 2001). The creation of the environments that enhance EV and POS should be used as behavioural criteria in evaluating the performance of managers. In this way, managers will make the creation of these environments a priority continually in their daily interaction with subordinates.

The study is based on cross-sectional methodology, and so common method variance cannot be completely removed. However, the unrotated factor analysis indicated that the level was acceptable. Causality also cannot be established because of the methodology utilised. Future studies should explore the role of other boundary variables created by leadership behaviour as possible mediators of the relationship between leadership style and employee engagement. The role of individual differences such as work role centrality should be considered. When individuals 'develop expectation of appropriate behaviour and internalise same, they define their self by that role' (Zhang \& Bartol, 2010, p. 111). Such a role identity is used to explain events and channel behaviour. Hence, such an individual may speak up even when the environment is not favourable. To enhance generalisation, future studies should expand the work to include other companies in additional industries.

\section{References}

Allen, D. G., Shore, L. M., \& Griffeth, R. W. (2003). The role of perceived organizational support and supportive human resource practices in the turnover process. Journal of Management, 29(1), 99-118. https://doi.org/10.1177/014920630302900107

Amah, O. E. (2017). Leadership styles and relational energy in high quality mentoring relationship. Indian Journal of Industrial Relations, 53(1), 59-71.

Amah, O. E. (2018). Determining the antecedents and outcomes of servant leadership. Journal of General Management, 43(3), 126-138. https://doi.org/10.1177/ 0306307017749634

Amah, O. E., \& Okafor, C. A. (2008a). Relationship among silence climate, employee silence behavior and work attitudes: The role of self-esteem and focus of control. Asian Journal of Scientific Research, 1(1), 1-11. https://doi.org/10.3923/ ajsr.2008.1.11

Amah, O. E., \& Okafor, C. A. (2008b). The interactive effect of organizational politics in the justice, organizational support and job satisfaction relationship. Asian Journal of Scientific Research, 1(5), 492-501. https://doi.org/10.3923/ajsr.2008.492.501

Amah, O. E., \& Sese, E. (2018). Relational energy \& employee engagement: Role of employee voice \& organizational support, Indian Journal of Industrial Relations, 53(3), 475-487.

Anikan, D. O., \& Oyewole, A. A. (2014). The influence of individual and organizational factors on employee engagement. International Journal of Development and Sustainability, 3(6), 1381-1392.

Aryee, S., Chen, Z. X., Sun, L. Y., \& Debrah, Y. A. (2007). Antecedents and outcomes of abusive supervision: Test of a trickle-down model. Journal of Applied Psychology, 92(1), 191-201. https://doi.org/10.1037/0021-9010.92.1.191

Blau, P. M. (1964). Exchange and power in social life. New York: Wiley Press. 
Breevaart, K., Bakker, A., Hetland, J., Demerouti, E., Olsen, O. K., \& Espevik, R. (2014). Daily transactional and transformational leadership and daily employee engagement Journal of Occupational and Organizational Psychology, 87(1), 138157. https://doi.org/10.1111/joop.12041

Budd, J., \& Zagelmeyer, S. (2010). Public policy and employee participation. In A. Wilkinson, P. Gollan, M. Marchington, \& D. Lewin. (Eds.), The Oxford handbook of participation in organizations (pp. 476-499). Oxford: Oxford University Press.

Chan, K., \& Drasgow, F. (2001). Toward a theory of individual differences and leadership: Understanding the motivation to lead. Journal of Applied Psychology, 86, 481-498. https://doi.org/10.1037/0021-9010.86.3.481

Cheng, B. S., Chou, L. F., Wu, T. Y., Huang, M. P., \& Farh, J. L. (2004). Paternalistic leadership and subordinate responses: Establishing a leadership model in Chinese organizations. Asian Journal of Social Psychology, 7(1), 89-117. https://doi. org/10.1111/j.1467-839X.2004.00137x

Dean, K. W. (2008). Values-based leadership: How our personal values impact the workplace. Journal of Values Based Leadership, 1(1), 59-66.

Eisenberger, R., Armeli, S., Rexwinkel, B., Lynch, P. D., \& Rhoades, L. (2001) Reciprocation of perceived organizational support. Journal of Applied Psychology 86(1), 42. https://doi.org/10.1037/0021-9010.86.1.42

Eisenberger, B., Huntington, R., Hutchinson, S., \& Sowa, D. (1986). Perceived organizational support. Journal of Applied Psychology, 71(1), 500-507. https:// doi.org/10.1037/0021-9010.71.3.500

Gouldner, A. W. (1960). The norm of reciprocity: A preliminary statement. Americana Sociological Review, 25, 161-171. https://doi.org/10.2307/2092623

Graen, G. B., Liden, R. C., \& Hoel, W. (1982). Role of leadership in the employee withdrawal process. Journal of Applied Psychology, 67(6), 868-875. https://doi. org/10.1037/0021-9010.67.6.868

Gregory Stone, A., Russell, R. F., \& Patterson, K., (2004). Transformational versus servan leadership: A difference in leader focus. Leadership \& Organization Development Journal, 25(4), 349-361. https://doi.org/10.1108/01437730410538671

Gul, S., Ahmad, B., Rehman, S. U., Shabir, N., \& Razzaq, N. (2012). Leadership style, turnover intention and the mediating role of organizational commitment Information and Knowledge Management, 2(7), 44-51.

Hair, J. F. Jr., Black, W. C., Babin, B. J., Anderson, R. E., \& Tatham, R. L. (2010). Multivariate data analysis, 7th edn., Pearson Prentice-Hall, Upper Saddle River, NJ.

Hanninen, L. E. (2017). Employee engagement in Borealis: Case study. Master's thesis. Aalto University School of Business, Management and International Business.

Harter, J. K., Schmidt, F. L., \& Hayes, T. L. (2002). Business-unit-level relationship between employee satisfaction, employee engagement, and business outcomes: A meta-analysis. Journal of Applied Psychology, 87(2), 268-279. https://doi. org/10.1037/0021-9010.87.2.268

Hoch, J. E., Bommer, W. H., Dulebohn, J. H., \& Wu, D. (2018). Do ethical, authentic, and servant leadership explain variance above and beyond transformational leadership?. Journal of Management, 44(2), 501-529. https://doi.org/10.1177/ 0149206316665461

Hollander, E. P. (1986). On the central role of leadership processes. Applied Psychology, 35(1), 39-52. https://doi.org/10.1111/j.1464-0597.1986.tb01273.x

$\mathrm{Hu}$, L. T., \& Bentler, P. M. (1999). Cutoff criteria for fit indexes in covariance structure analysis: Conventional criteria versus new alternatives. Structural Equation Modeling, 6, 1-55. https://doi.org/10.1080/10705519909540118

Ismail, A., Mohamad, M. H., Mohamed, H. A. B., Rafiuddin, N. M., \& Zhen, K. W. P. (2010). Transformational and transactional leadership styles as a predictor of individual outcomes. Theoretical \& Applied Economics, 17(6), 89-104.

Kahn, W. A. (1990). Psychological conditions of personal engagement and disengagement at work. Academy of Management Journal, 33(4), 692-724.

Khan, S. L. (2015). Transformational leadership and turnover intention: The mediating effects of trust and performance. Doctoral dissertation. Bangkok University.

Koene, B. A., Vogelaar, A. L., \& Soeters, J. L. (2002). Leadership effects on organizational climate and financial performance: Local leadership effect in chain organizations. The Leadership Quarterly, 13(3), 193-215. https://doi.org/10.1016/S1048 9843(02)00103-0

Koufteros, X. A., Vonderembse, M. A., \& Doll, W. J. (2002). Examining the competitive capabilities of manufacturing firms. Structural Equation Modeling, 9(2), 256-282. https://doi.org/10.1207/S15328007SEM0902_6

Kruse, K. (2012). Employee engagement: How to motivate your team for high performance. Richboro, PA: The Kruse Group.
Levinson, H. (1980). Power, leadership, and the management of stress. Professional Psychology, 11(1), 497-508. https://doi.org/10.1037/0735-7028.11.3.497

Liden, R. C., Wayne, S. J., Meuser, J. D., Hu, J., Wu, J., \& Liao, C. (2015). Servant eadership: Validation of a short form of the SL-28. The Leadership Quarterly, 26(2), 254-269. https://doi.org/10.1016/j.leaqua.2014.12.002

May, D. R., Gilson, R. L., \& Harter, L. M. (2004). The psychological conditions of meaningfulness, safety and availability and the engagement of the human spirit at work. Journal of Occupational and Organizational Psychology, 77(1), 11-37. https://doi.org/10.1348/096317904322915892

Morrison, E. W., Wheeler-Smith, S. L., \& Kamdar, D. (2011). Speaking up in groups: A cross-level study of group voice climate and voice. Journal of Applied Psychology 96(1), 183-191. https://doi.org/10.1037/a0020744

National Bureau of Statistics (2017). Labour force statistics Vol. 1: Unemployment and underemployment report. National Bureau of Statistics (NBS), Abuja. https:// nigerianstat.gov.ng/download/694.

Nunnally, J. (1978). Psychometric theory. New York: McGraw-Hill.

Podsakoff, P. M., \& Organ, D. W. (1986). Self-report in organizational research: Problems and prospects. Journal of Management, 12(4), 545-560. https://doi. org/10.1177/014920638601200408

Rees, C., Alfes, K., \& Gatenby, M. (2013). Employee voice and engagement Connections and consequences. The International Journal of Human Resource Management, 24(14), 2780-2798. https://doi.org/10.1080/09585192.2013.76 3843

Robinson Jr, J. R. (2018). Employee engagement: Exploring the experiences of how voice and silence relate to public sector employees' feeling of being engaged. PhD Dissertation. ProQuest Dissertation Publishing, George Washington University, USA. Retrieved from: https://search.proquest.com/openview/1f51e0f14d7da869 $8 \mathrm{ac} 5 \mathrm{fb} 3587 \mathrm{~d} 4 \mathrm{e} 1 \mathrm{fc} / 1$ ?pq-origsite=gscholar \&cbl=18750\&diss=y

Rothmann, S., \& Rothmann, S. (2010). Factors associated with employee engagement in South Africa. South African Journal of Industrial Psychology, 36(2), 12. https:// doi.org/10.4102/sajip.v36i2.925

Savage-Austin, A. R., \& Honeycutt, A. (2011). Servant leadership: A phenomenologica study of practices, experiences, organizational effectiveness, and barriers. Journa of Business \& Economics Research, 9(1), 49-54. https://doi.org/10.19030/jber. v9i1.939

Schaufeli, W.B, Bakker, A. B., \& Salanova, M. (2002). The measurement of work engagement with a short questionnaire: A cross-national study. Education and Psychological Measurement, 66, 701-716.

Schuh, S. C., Zhang, X. A., \& Tian, P. (2013). For the good or the bad? Interactive effects of transformational leadership with moral and authoritarian leadership behaviors. Journal of Business Ethics, 116(3), 629-640. https://doi.org/10.1007/s10551-0121486-0

Sriram, V. V. (2012). Developmental challenges for 21st century. Bonfring International Journal of Engineering and Management Sciences, 2(1), 14-16.

Ugwu, F. O. (2013). Work engagement in Nigeria: Adaptation is the Utretch Work Engagement scale for Nigerian samples. International Journal of Multidisciplinary Academic Research, 1(3), 16-26.

Ugwu, F. O., Onyishi, I. E., \& Rodriguez-Sanchez, A. M. (2014). Linking organizational trust and employee engagement: The role of psychological empowerment. Personnel Review, 43(3), 377-400. https://doi.org/10.1108/PR-11-2012-0198

Vakola, M., \& Dimitras, B. (2005). Antecedents and consequences of organizational silence: An empirical investigation. Employee Relations, 22(5), 441-458. https:// silence: An empirical investigation. Emplo
doi.org/10.1108/01425450510611997

Van Dierendonck, D. (2011). Servant leadership: A review and synthesis. Journal of Management, 37, 1228-1261. https://doi.org/10.1177/0149206310380462

Van Dyne, L., \& LePine, J. A. (1998). Helping and voice extra-role behaviors: Evidence of construct and predictive validity. Academy of Management Journal, 41(1), 108-119.

Wang, D. S., \& Hsieh, C. C. (2013). The effect of authentic leadership on employee trust and employee engagement. Social Behavior and Personality: An International Journal, 41(4), 613-624. https://doi.org/10.2224/sbp.2013.41.4.613

Young, S. (2014). Global trends in employee attraction, retention and engagement. HR Matters, 7(1), 7-9.

Zhang, X., \& Bartol, K. M. (2010). Linking empowering leadership and employee creativity: The influence of psychological empowerment, intrinsic motivation, and
creative process engagement. Academy of Management Journal, 53(1), 107-128. creative process engagement. Academy of Mand
https://doi.org/10.5465/amj.2010.48037118 